\title{
Conversion of the Cluster Core Structure via CO Elimination and Activation of the Coordinated Hydrocarbon Ligand. Synthesis and Reactions of $\mathrm{WOs}_{3} \mathrm{Cp}(\mathrm{CO})_{10}(\mathrm{CMeCMeCCPh})$
}

\author{
Yun Chi,* ${ }^{a}$ Hui-Ying Hsu, ${ }^{a}$ Shie-Ming Pengt ${ }^{b}$ and Gene-Hsiang Lee ${ }^{b}$ \\ a Department of Chemistry, National Tsing Hua University, Hsinchu 30043, Taiwan \\ b Department of Chemistry, National Taiwan University, Taipei 10764, Taiwan
}

Reaction of $\mathrm{WCp}(\mathrm{CO})_{3} \mathrm{C} \equiv \mathrm{CPh}$ with $\mathrm{Os}_{3}(\mathrm{CO})_{10}\left(\mathrm{C}_{2} \mathrm{Me}_{2}\right)$ produced the butterfly cluster $\mathrm{WOs}_{3} \mathrm{Cp}(\mathrm{CO})_{10}(\mathrm{CMeCMeCCPh}) 1$ in moderate yield; treatment of 1 with $\mathrm{Me}_{3} \mathrm{NO}$ followed by thermolysis in refluxing toluene yielded the spiked triangular cluster $\mathrm{WOs}_{3} \mathrm{Cp}(\mathrm{CO})_{9}(\mu-\mathrm{H})\left[\mathrm{CMeCMeCC}\left(\mu_{2}-\eta^{2}-\mathrm{C}_{6} \mathrm{H}_{4}\right)\right] 3$ as a major product; on further thermolysis, complex 3 reconverted to a butterfly cluster WOs ${ }_{3} \mathrm{Cp}(\mathrm{CO})_{9}\left[\mathrm{CMeCMeCHC}\left(\mu_{2}-\eta^{2}-\mathrm{C}_{6} \mathrm{H}_{4}\right)\right] 5$ and then to a tetrahedral cluster $\mathrm{WOs}_{3} \mathrm{Cp}(\mathrm{CO})_{8}\left[\mathrm{CMeCMeCHC}\left(\mu_{2}-\eta^{2}-\mathrm{C}_{6} \mathrm{H}_{4}\right)\right] 6$ via hydride migration followed by loss of $\mathrm{CO}$; the structures of complexes 3,5 and 6 have been determined by $X$-ray diffraction.

Systematically increasing the nuclearity of cluster compounds and transformation of the cluster core geometries continues to be a challenging and important task in the chemistry of transition metal cluster complexes. ${ }^{1}$ We have been exploring the use of group 6 mononuclear metal acetylide ${ }^{2}$ and hydride ${ }^{3}$ complexes in the stepwise synthesis of heterometallic cluster complexes; the preparation of the butterfly cluster complex $\mathrm{WO}_{3} \mathrm{Cp}(\mathrm{CO})_{10}(\mathrm{CMeCMeCCPh}) 1$ containing a multi-site bound $\mathrm{C}_{4}$ hydrocarbon ligand has been achieved. Herein we report the activation of this $\mathrm{C}_{4}$ hydrocarbon ligand via $\mathrm{CO}$ elimination and the sequential conversion of the cluster core from the spiked triangle to the tetrahedral arrangement.

Treatment of $\mathrm{WCp}(\mathrm{CO})_{3} \mathrm{C} \equiv \mathrm{CPh}^{4}$ and $\mathrm{Os}_{3}(\mathrm{CO})_{10}\left(\mathrm{C}_{2} \mathrm{Me}_{2}\right)^{5}$ in $1: 1$ molar ratio and in refluxing toluene $\left(110^{\circ} \mathrm{C}, 40 \mathrm{~min}\right)$ yielded two condensation products $\mathrm{WOs}_{3} \mathrm{Cp}(\mathrm{CO})_{10}(\mathrm{CMe}-$ $\mathrm{CMeCCPh}) 1(41 \%)$ and $\mathrm{WO}_{3} \mathrm{Cp}(\mathrm{CO})_{9}(\mathrm{CCPhCMeCMe}) 2$ $(33 \%)$ (Scheme 1). Both complexes 1 and 2 were characterized by mass, IR and NMR spectroscopy. $\ddagger$ The exact

\section{$\dagger$ For crystallographic enquiries.}

$\$$ Spectral data for 1: MS (FAB, $\left.{ }^{184} \mathrm{~W},{ }^{192} \mathrm{Os}\right), \mathrm{m} / z 1260\left(\mathrm{M}^{+}\right)$. IR $\left(\mathrm{C}_{6} \mathrm{H}_{12}\right) \mathrm{v}(\mathrm{CO}) / \mathrm{cm}^{-1} 2077 \mathrm{vs}, 2055 \mathrm{~s}, 2048 \mathrm{vs}, 2027 \mathrm{~m}, 2014 \mathrm{~s}, 2010 \mathrm{~s}$, $1997 \mathrm{~m}, 1975 \mathrm{~s}, 1968 \mathrm{~s}, 1952 \mathrm{vw}$ and $1940 \mathrm{~m} ;{ }^{1} \mathrm{H} \mathrm{NMR}\left(400 \mathrm{MHz}, \mathrm{CDCl}_{3}\right.$, $294 \mathrm{~K}) \delta 7.45\left(\mathrm{~d}, 2 \mathrm{H}, J_{\mathrm{H}-\mathrm{H}} 7.4 \mathrm{~Hz}\right), 7.39-7.32(\mathrm{~m}, 3 \mathrm{H}), 5.14(\mathrm{~s}, 5 \mathrm{H})$, $2.98(\mathrm{~s}, 3 \mathrm{H})$ and $1.88(\mathrm{~s}, 3 \mathrm{H}) ;{ }^{13} \mathrm{C} \mathrm{NMR}\left(100 \mathrm{MHz}, \mathrm{CD}_{2} \mathrm{Cl}_{2}, 254 \mathrm{~K}\right)$ $\delta 217.0\left(J_{\mathrm{W}-\mathrm{C}} 149 \mathrm{~Hz}\right), 186.0(\mathrm{br}), 183.6,183.3,183.2(\mathrm{br}), 182.9$, $182.4,179.1$ (br), 179.0, 173.2 (CO), 193.3, 156.7, 146.6, 144.0, 134.9 (ipso- $\left.\mathrm{C}_{6} \mathrm{H}_{5}\right), 129.2\left(o, m-\mathrm{C}_{6} \mathrm{H}_{5}\right), 127.7\left(p-\mathrm{C}_{6} \mathrm{H}_{5}\right), 90.9(5 \mathrm{C}), 39.1$ (Me), $23.3(\mathrm{Me})$. Spectral data for 2: MS, $m / z$ 1232(M+). IR $\left(\mathrm{C}_{6} \mathrm{H}_{12}\right)$ $v(\mathrm{CO}) / \mathrm{cm}^{-1} 2075 \mathrm{~s}, 2047 \mathrm{vs}, 2004 \mathrm{~m}, 1993 \mathrm{vs}, 1972 \mathrm{vw}, 1958 \mathrm{w}, 1939 \mathrm{w}$ and $1850 \mathrm{br}, \mathrm{vw} ;{ }^{1} \mathrm{H}$ NMR $\left(400 \mathrm{MHz}, \mathrm{CDCl}_{3}, 294 \mathrm{~K}\right) \delta 7.70(\mathrm{~d}, 2 \mathrm{H}$, $\left.J_{\mathrm{H}-\mathrm{H}} 7.7 \mathrm{~Hz}\right), 7.47\left(\mathrm{t}, 2 \mathrm{H}, J_{\mathrm{H}-\mathrm{H}} 8.4 \mathrm{~Hz}\right), 7.39\left(\mathrm{t}, 1 \mathrm{H}, J_{\mathrm{H}-\mathrm{H}} 7.4 \mathrm{~Hz}\right)$, $5.36(\mathrm{~s}, 5 \mathrm{H}), 2.47(\mathrm{~s}, 3 \mathrm{H})$ and $2.28(\mathrm{~s}, 3 \mathrm{H}) ;{ }^{13} \mathrm{C} \mathrm{NMR}(100 \mathrm{MHz}$, $\left.\mathrm{CD}_{2} \mathrm{Cl}_{2}, 300 \mathrm{~K}\right) \delta 231.2\left(J_{\mathrm{W}-\mathrm{C}} 136 \mathrm{~Hz}\right), 187.0,186.0,180.8(\mathrm{br}, 3 \mathrm{C})$, molecular structures of these complexes were established by comparing their IR spectra with those of the structurally characterized cluster complexes $\mathrm{WOs}_{3} \mathrm{Cp}(\mathrm{CO})_{10}[\mathrm{C}$ $\left.\left(\mathrm{CO}_{2} \mathrm{Et}\right) \mathrm{C}\left(\mathrm{CO}_{2} \mathrm{Et}\right) \mathrm{CCPh}\right]$ and $\mathrm{WOs}_{3} \mathrm{Cp}(\mathrm{CO})_{9}[\mathrm{CCPhC}-$ (Tol)C(Tol)], respectively. ${ }^{6}$ It is evident that the tetranuclear butterfly cluster complex 1 was produced by coupling of the coordinated alkyne with the $\alpha$-carbon of the incoming acetylide ligand, while complex 2 was produced by coupling with the $\beta$-carbon. Both complexes display some interesting reactivity patterns and we here focus on the transformation of the cluster cores starting from complex 1.

Treatment of 1 with $\mathrm{Me}_{3} \mathrm{NO}$ ( 1.1 mol equiv.) in a mixture of acetonitrile-dichloromethane at ambient temperature followed by heating in refluxing toluene produced a burgundycoloured solution within ten minutes. Following TLC separation (hexane-dichloromethane $4: 1$ ) and purification by recrystallization, we obtained a wine-red cluster $\mathrm{WOs}_{3} \mathrm{Cp}(\mathrm{CO})_{9^{-}}$ $(\mu-\mathrm{H})\left[\mathrm{CMeCMeCC}\left(\mu_{2}-\eta^{2}-\mathrm{C}_{6} \mathrm{H}_{4}\right)\right] 3$ in $48 \%$ yield, in addition

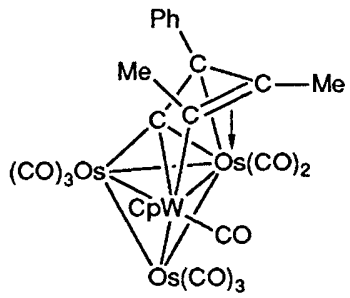

2

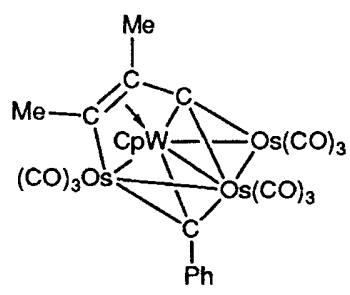

4
$177.3(3 \mathrm{C}) ; \delta 237.5\left(J_{\mathrm{W}-\mathrm{C}} 68 \mathrm{~Hz}\right), 156.7\left(J_{\mathrm{W}-\mathrm{C}} 88 \mathrm{~Hz}\right), 137.3,135.1$, $\left(J_{\mathrm{W}-\mathrm{C}} 14 \mathrm{~Hz}\right), 133.2(2 \mathrm{C}), 129.7,129.2(2 \mathrm{C}), 120.3,92.6(5 \mathrm{C}), 30.9$ (Me) and $19.2(\mathrm{Me})$. Satisfactory elemental analyses were obtained for 1 and 2. 


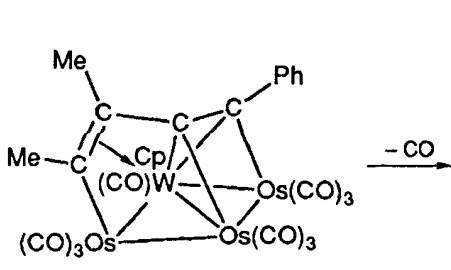

1

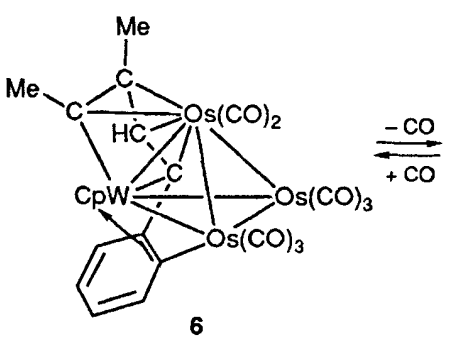

6

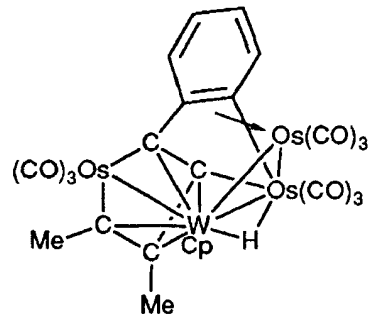

3

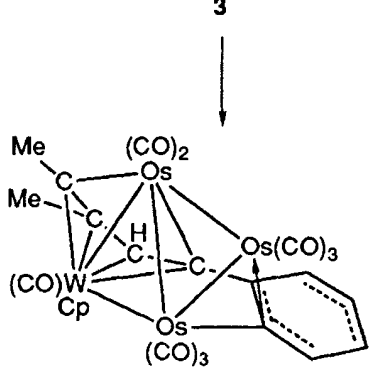

5

Scheme 1

to an orange cluster $\mathrm{WOs}_{3} \mathrm{Cp}(\mathrm{CO})_{9}\left(\mu_{3}-\mathrm{CPh}\right)(\mathrm{CCMeCMe}) 4$ $(18 \%)$. $\S$ Complex 3 was produced by the activation of the phenyl substituent of the $\mathrm{C}_{4}$ hydrocarbon. Its ${ }^{1} \mathrm{H}$ NMR spectrum exhibits four aromatic proton signals within the range $\delta 8.49-6.59$ and a hydride signal at $\delta-14.26$ with the characteristic tungsten-hydrogen coupling $J_{\mathrm{W}-\mathrm{H}} 73.8 \mathrm{~Hz}$. In contrast, complex 4 was formed by $\mathrm{C}-\mathrm{C}$ bond scission of the carbon chain. Its structure was unambiguously established by comparison of its solution IR $v(\mathrm{CO})$ spectrum with that of the related derivative $\mathrm{WOs}_{3} \mathrm{Cp}(\mathrm{CO})_{9}\left(\mu_{3}-\mathrm{CPh}\right)[\mathrm{CC}(\mathrm{Tol}) \mathrm{C}(\mathrm{Tol})]$ generated from the direct thermal reaction between $\mathrm{WCp}(\mathrm{CO})_{3} \mathrm{C} \equiv \mathrm{CPh}$ and $\mathrm{Os}_{3}(\mathrm{CO})_{10}\left(\mathrm{C}_{2} \mathrm{Tol}_{2}\right) \cdot{ }^{7}$

Complex 3 was examined by single-crystal X-ray diffraction. T The complex consists of two crystallographically distinct, but structurally similar molecules in the lattices; each displays a 'spiked-triangular' core arrangement with the tungsten atom located at the centre positions. An ORTEP diagram of one molecule is presented in Fig. 1. The osmium atom $\mathrm{Os}(3 \mathrm{~A})$ and the $\mathrm{C}_{4}$ hydrocarbon backbone are arranged like a metallacyclopentadienyl fragment, ${ }^{8}$ which coordinates to the tungsten atom via two alkenic $\pi$-interactions and a $\mathrm{W}-\mathrm{Os}$ interaction and also links to a metal atom via the

$\S$ Spectral data for 3: MS, $\mathrm{m} / \mathrm{z} 1232\left(\mathrm{M}^{+}\right)$. IR $\left(\mathrm{C}_{6} \mathrm{H}_{12}\right) v(\mathrm{CO}) / \mathrm{cm}^{-1}$ $2069 \mathrm{vw}, 2053 \mathrm{vs}, 2036 \mathrm{vs}, 1997 \mathrm{~m}, 1987 \mathrm{~m}, 1975 \mathrm{~s}$ and $1956 \mathrm{w} ;{ }^{1} \mathrm{H}$ NMR $\left(400 \mathrm{MHz}, \mathrm{CDCl}_{3}, 294 \mathrm{~K}\right) \delta 8.49\left(\mathrm{~d}, 1 \mathrm{H}, J_{\mathrm{H}-\mathrm{H}} 8.2 \mathrm{~Hz}\right), 7.59(\mathrm{~d}, 1 \mathrm{H}$, $\left.J_{\mathrm{H}-\mathrm{H}} 8.7 \mathrm{~Hz}\right), 7.03\left(\mathrm{t}, 1 \mathrm{H}, J_{\mathrm{H}-\mathrm{H}} 7.7 \mathrm{~Hz}\right), 6.59\left(\mathrm{t}, 1 \mathrm{H}, J_{\mathrm{H}-\mathrm{H}} 7.3 \mathrm{~Hz}\right)$, $5.23(\mathrm{~s}, 5 \mathrm{H}), 2.53(\mathrm{~s}, 3 \mathrm{H}), 2.46(\mathrm{~s}, 3 \mathrm{H})$ and $-14.26\left(\mathrm{~s}, 1 \mathrm{H}, J_{\mathrm{W}-\mathrm{H}} 73.8\right.$ $\mathrm{Hz}) ;{ }^{13} \mathrm{C} \mathrm{NMR}\left(100 \mathrm{MHz}, \mathrm{CDCl}_{3}, 253 \mathrm{~K}\right) \delta 184.9(3 \mathrm{C}), 180.5,179.8$ (2 C) $, 177.2,175.5,175.3,174.0,156.7,154.1,147.8,141.1,127.0$, $122.8,117.8,114.3,107.0\left(J_{\mathrm{C}-\mathrm{W}} 11 \mathrm{~Hz}\right), 89.0(5 \mathrm{C}), 32.4(\mathrm{Me}), 19.2$ (Me). Spectral data for 4: MS, $m / z 1232\left(\mathrm{M}^{+}\right)$. IR $\left(\mathrm{C}_{6} \mathrm{H}_{12}\right)$ $v(\mathrm{CO}) / \mathrm{cm}^{-1}, 2076 \mathrm{~s}, 2044 \mathrm{vs}, 2035 \mathrm{~m}, 2018 \mathrm{~s}, 1997 \mathrm{vw}, 1975 \mathrm{~m}, 1959 \mathrm{~s}$ and $1914 \mathrm{br}, \mathrm{w} ;{ }^{1} \mathrm{H}$ NMR $\left(400 \mathrm{MHz}, \mathrm{CD}_{2} \mathrm{Cl}_{2}, 294 \mathrm{~K}\right): \delta 7.16\left(\mathrm{t}, 2 \mathrm{H}, J_{\mathrm{H}-\mathrm{H}}\right.$ $7.8 \mathrm{~Hz}), 7.05\left(\mathrm{t}, 1 \mathrm{H}, J_{\mathrm{H}-\mathrm{H}} 7.3 \mathrm{~Hz}\right), 6.80\left(\mathrm{~d}, 2 \mathrm{H}, J_{\mathrm{H}-\mathrm{H}} 6.5 \mathrm{~Hz}\right), 5.23(\mathrm{~s}$, $5 \mathrm{H}), 3.39(\mathrm{~s}, 3 \mathrm{H})$ and $2.09(\mathrm{~s}, 3 \mathrm{H}) ;{ }^{13} \mathrm{C} \mathrm{NMR}\left(100 \mathrm{MHz}, \mathrm{CD}_{2} \mathrm{Cl}_{2}\right.$, 294 K) Os-CO o 185.6, 183.2, 180.7, 179.8, 178.9, 176.5, (3C), 172.1; $\delta 236.1,192.0,162.2,136.7,130.6,128.8(2 \mathrm{C}), 127.2(2 \mathrm{C}), 96.5(5 \mathrm{C})$, $39.2(\mathrm{Me})$ and $32.1(\mathrm{Me})$. Satisfactory elemental analyses were obtained for 3 and 4

I. Crystal data for 3: $\mathrm{C}_{26} \mathrm{H}_{15} \mathrm{O}_{9} \mathrm{Os}_{3} \mathrm{~W}_{1}, M=1225.85$, monoclinic, space group $P 2_{1} / n, a=19.596(6), b=15.288(4), c=20.352(6) \AA, \beta=$ $118.63(2)^{\circ}, U=5352(3) \AA^{3}, Z=8, D_{c}=3.043 \mathrm{~g} \mathrm{~cm}^{-3}, F(000)=4358$, Nonius CAD-4 diffractometer with Mo-K $\alpha$ radiation, $\lambda=0.7930 \AA$, $\mu(\mathrm{Mo}-\mathrm{K} \alpha)=18.65 \mathrm{~mm}^{-1} . R=0.050, R_{\mathrm{w}}=0.045$ for total 6979 reflections and 5217 reflections with $I>2.0 \sigma(I)$. Atomic coordinates, bond lengths and angles, and thermal parameters have been deposited at the Cambridge Crystallographic Data Centre for 3,5 and 6. See Notice to Authors, Issue No. 1.

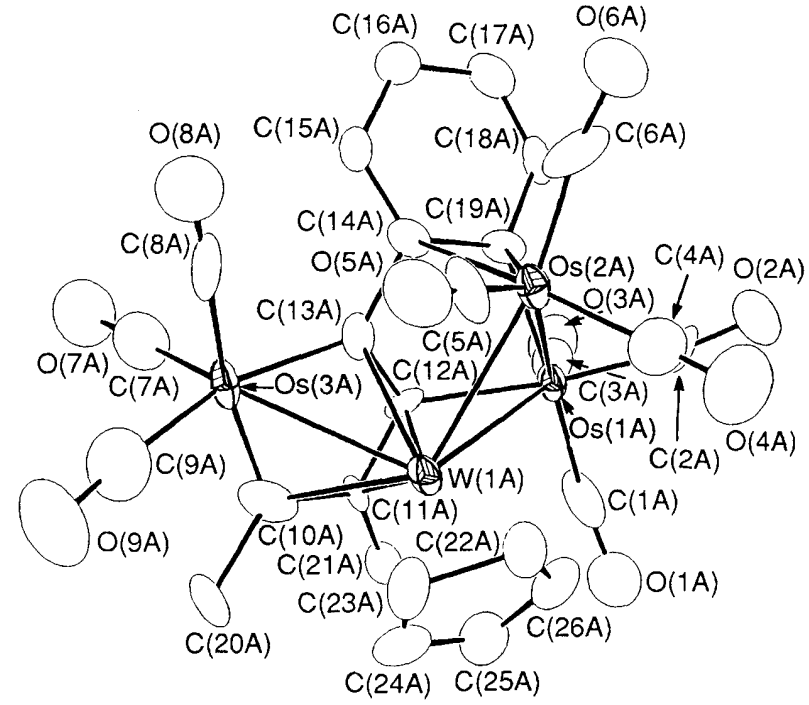

Fig. 1 The molecular drawing of complex 3 . Bond lengths $(\AA)$ : Os(1A)-Os(2A) 2.836(2), Os(1A)-W(1A) 2.987(2), Os(2A)-W(1A) 2.862(2), Os(3a)-W(1A) 2.865(2), Os(1A)-C(12A) 2.10(3), Os(1A)C(19A) 2.06(3), Os(2A)-C(14A) 2.36(3), Os(2A)-C(19A) 2.21(3), $\mathrm{Os}(3 \mathrm{~A})-\mathrm{C}(10 \mathrm{~A})$ 1.96(3), Os(3A)-C(13A) 2.15(3), W(1A)-C(10A) $2.38(3), \mathrm{W}(1 \mathrm{~A})-\mathrm{C}(11 \mathrm{~A}) 2.23(3), \mathrm{W}(1 \mathrm{~A})-\mathrm{C}(12 \mathrm{~A}) 2.19(3), \mathrm{W}(1 \mathrm{~A})-$ $\mathrm{C}(13 \mathrm{~A}) 2.35(3), \mathrm{C}(11 \mathrm{~A})-\mathrm{C}(12 \mathrm{~A}) 1.45(3), \mathrm{C}(12 \mathrm{~A})-\mathrm{C}(13 \mathrm{~A}) 1.38(4)$, $\mathrm{C}(13 \mathrm{~A})-\mathrm{C}(14 \mathrm{~A}) 1.51(4), \mathrm{C}(14 \mathrm{~A})-\mathrm{C}(19 \mathrm{~A}) 1.41(4), \mathrm{C}(14 \mathrm{~A})-\mathrm{C}(15 \mathrm{~A})$ $1.42(4), \mathrm{C}(15 \mathrm{~A})-\mathrm{C}(16 \mathrm{~A}) 1.40(4), \mathrm{C}(16 \mathrm{~A})-\mathrm{C}(17 \mathrm{~A}) 1.45(4), \mathrm{C}(17 \mathrm{~A})-$ $\mathrm{C}(18 \mathrm{~A}) 1.37(4)$ and $\mathrm{C}(18 \mathrm{~A})-\mathrm{C}(19 \mathrm{~A}) 1.47(4)$.

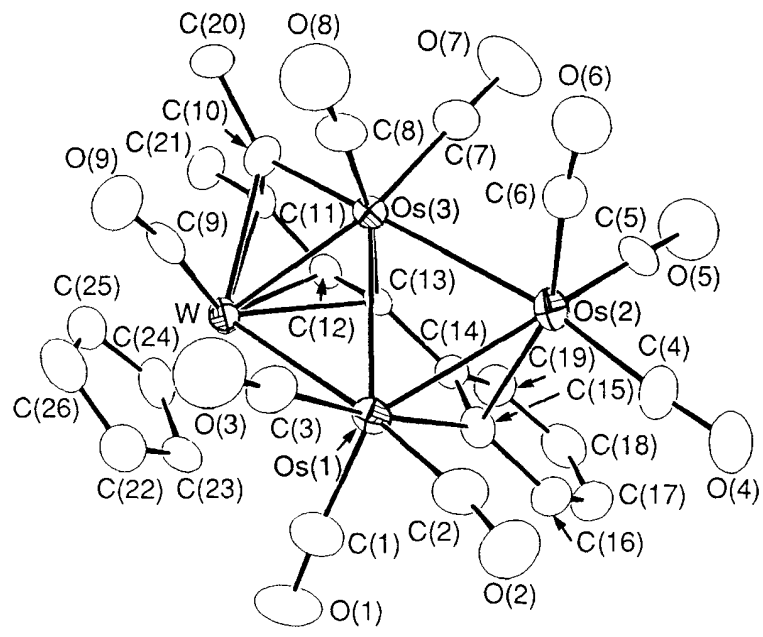

Fig. 2 The molecular drawing of 5. Bond lengths $(\AA)$ : Os $(1)-\operatorname{Os}(2)$ 2.743(1), Os(1)-Os(3) 2.827(1), Os(1)-W 3.107(1), Os(2)-Os(3) $2.779(1)$, Os(3)-W 2.680(1), Os(1)-C(15) $2.22(1)$, Os(2) $\cdots \mathrm{C}(14)$ $2.98(1), \operatorname{Os}(2)-\mathrm{C}(15) 2.33(1), \operatorname{Os}(3)-\mathrm{C}(10) 2.08(1), \operatorname{Os}(3)-\mathrm{C}(13)$ $2.10(1)$, W-C(10) 2.30(1), W-C(11) 2.33(1), W-C(12) 2.36(1), W-C(13) 2.28(1), C(10)-C(11) $1.50(2), C(11)-C(12) 1.42(2), C(12)-$ $\mathrm{C}(13) 1.39(2), \mathrm{C}(13)-\mathrm{C}(14) 1.46(2), \mathrm{C}(14)-\mathrm{C}(15) 1.41(2), \mathrm{C}(14)-$ $\mathrm{C}(19) 1.39(2), \mathrm{C}(15)-\mathrm{C}(16) 1.42(2), \mathrm{C}(16)-\mathrm{C}(17) 1.38(2), \mathrm{C}(17)-$ $\mathrm{C}(18) 1.37(2)$ and $\mathrm{C}(18)-\mathrm{C}(19) 1.38(2)$.

$\mathrm{C}(12 \mathrm{~A})-\mathrm{Os}(1 \mathrm{~A})$ bond. The phenyl substituent is now bound to the atom Os(1A) of the $\mathrm{WOs}_{2}$ metal triangle and to the atom $\operatorname{Os}(2 \mathrm{~A})$ via $\eta^{2}$-coordination. This same bonding is seen in the pyrolysis products of triosmium and triruthenium phenylphosphine complexes. ${ }^{9}$ Finally, the bridging hydride is proposed to be associated with the $\mathrm{W}(1 \mathrm{~A})-\mathrm{Os}(1 \mathrm{~A})$ bond, because its bond length is the longest of the three $\mathrm{W}-\mathrm{O}$ s bonds in the molecule.

Further pyrolysis of $\mathbf{3}$ in refluxing toluene as solvent for $2.5 \mathrm{~h}$, inducing the hydride migration to the coordinated $\mathrm{C}_{4}$ hydrocarbon, produced two cluster derivatives $\mathrm{WO}_{3} \mathrm{Cp}(\mathrm{CO})_{9}\left[\mathrm{CMeCMeCHC}\left(\mu_{2}-\eta^{2}-\mathrm{C}_{6} \mathrm{H}_{4}\right)\right] \mathbf{5}$ and $\mathrm{WOs}_{3} \mathrm{Cp}-$ $(\mathrm{CO})_{8}\left[\mathrm{CMeCMeCHC}\left(\mu_{2}-\eta^{2}-\mathrm{C}_{6} \mathrm{H}_{4}\right)\right] 6$ in 26 and $31 \%$ yields, 
respectively (Scheme 1). These complexes underwent reversible equilibration in refluxing toluene, because heating a solution of either complex 5 or $\mathbf{6}$ produced a mixture of both complexes within $30 \mathrm{~min}$. $\|$ In addition, these complexes are stable at room temperature, which allows us to carry out the routine TLC separation and identification by elemental analysis, spectral methods** and X-ray diffraction. ${ }^{\dagger} \dagger$

The structure of 5 adopts an $\mathrm{Os}_{3} \mathrm{~W}$ butterfly core geometry with the tungsten atom sited at one of the 'wingtip' positions (dihedral angle $\left.177.32(1)^{\circ}\right)$. As indicated by its molecular drawing (Fig. 2), the bridging hydride of $\mathbf{3}$ is moved to the third carbon atom $\mathrm{C}(13)$ of the $\mathrm{C}_{4}$ hydrocarbon linkage, in which all four carbon atoms and the Os(3) atom take up a cyclic, planar disposition similar to complex 3. The phenyl substituent is linked to the $\mathrm{C}_{4}$ linkage via the $\mathrm{C}(13)-\mathrm{C}(14)$ bond and from the adjacent carbon atom $\mathrm{C}(15)$ which forms an asymmetric bridge over the Os(1)-Os(2) edge. The bonding between the phenyl group and the metal atoms is best described as the formation of Os(1)-C(15) $\sigma$-bond and of a $\pi$-interaction with Os(2) from a delocalized molecular orbital of appropriate symmetry which is centred at C(15). Lewis and Johnson have utilized a similar description to account for the bonding of benzyne moieties in several triosmium complexes. ${ }^{10}$

Complex 6 crystallized in the $P \overline{1}$ space group with two independent molecules in the unit cell. The ORTEP diagram of one molecule is shown in Fig. 3. As expected, the $\mathrm{Os}_{3} \mathrm{~W}$ cluster core consists of a tetrahedral geometry and the $\mathrm{C}_{4}$ fragment adopts a similar type of bonding arrangement, except that the phenyl group has migrated from an Os-Os edge to an Os-W edge. It is possible that the transformation from butterfly to tetrahedral is initiated by the removal of $\mathrm{CO}$ from the tungsten atom and the formation of a new Os-W bond. The migration of phenyl substituent and fine adjustment of the $\mathrm{C}_{4}$ chain plays the secondary role of balancing the number of formal electrons on each individual metal atom.

In summary, our work has provided an interesting example of changing the cluster framework from a butterfly to a spiked triangle, then back to a butterfly and, finally to a tetrahedral arrangement (Scheme 1). The coordinated hydrocarbon ligand serves as a reservoir to supply two pairs of electrons via ortho-metallation and complexation of the phenyl group via $\pi$-bonding to compensate the coordinative unsaturation generated during the formation of spiked triangular complex 3. The cluster core undergoes conversion to butterfly and then to tetrahedral via consecutive removal of two pairs of electrons as a result of hydride migration followed by loss of a second CO ligand. This sequence demonstrates some conceiv-

$\|$ Extending the reaction time to six hours induced further loss of $\mathrm{CO}$, giving another $\mathrm{Os}_{3} \mathrm{~W}$ cluster with eight $\mathrm{CO}$ ligands.

** Spectral data for 5: MS, $m / z 1232\left(\mathrm{M}^{+}\right)$. IR $\left(\mathrm{CH}_{2} \mathrm{Cl}_{2}\right) v(\mathrm{CO}) / \mathrm{cm}^{-1}$, $2060 \mathrm{~s}, 2022 \mathrm{~s}, 1982 \mathrm{vs}$, br and $1972 \mathrm{~m}, \mathrm{br} ;{ }^{1} \mathrm{H}$ NMR $\left(400 \mathrm{MHz}, \mathrm{CD}_{2} \mathrm{Cl}_{2}\right.$, $294 \mathrm{~K}) \delta 8.22\left(\mathrm{~d}, 1 \mathrm{H}, J_{\mathrm{H}-\mathrm{H}} 7.4 \mathrm{~Hz}\right), 7.77\left(\mathrm{t}, 1 \mathrm{H}, J_{\mathrm{H}-\mathrm{H}} 7.3 \mathrm{~Hz}\right), 7.26(\mathrm{~d}$, $\left.1 \mathrm{H}, J_{\mathrm{H}-\mathrm{H}} 7.9 \mathrm{~Hz}\right), 6.88(\mathrm{~s}, 1 \mathrm{H}), 6.55\left(\mathrm{t}, 1 \mathrm{H}, J_{\mathrm{H}-\mathrm{H}} 7.1 \mathrm{~Hz}\right), 4.82(\mathrm{~s}, 5$ $\mathrm{H}), 2.72(\mathrm{~s}, 3 \mathrm{H})$ and $2.32(\mathrm{~s}, 3 \mathrm{H})$. Spectral data for 6: MS, $\mathrm{m} / \mathrm{z} 1204$ $\left(\mathrm{M}^{+}\right)$. IR $\left(\mathrm{CCl}_{4}\right) v(\mathrm{CO}) / \mathrm{cm}^{-1} 2061 \mathrm{vs}, 2024 \mathrm{vs}, 1985 \mathrm{vs}, 1964 \mathrm{vw}$ and $1937 \mathrm{~m} ;{ }^{1} \mathrm{H}$ NMR $\left(400 \mathrm{MHz}, \mathrm{CD}_{2} \mathrm{Cl}_{2}, 294 \mathrm{~K}\right) \delta 7.79\left(\mathrm{~d}, 1 \mathrm{H}, J_{\mathrm{H}-\mathrm{H}} 8.1\right.$ $\mathrm{Hz}), 7.74\left(\mathrm{t}, 1 \mathrm{H}, J_{\mathrm{H}-\mathrm{H}} 7.3 \mathrm{~Hz}\right), 7.04\left(\mathrm{~d}, 1 \mathrm{H}, J_{\mathrm{H}-\mathrm{H}} 7.9 \mathrm{~Hz}\right), 6.82(\mathrm{~s}, 1$ $\mathrm{H}), 6.80\left(\mathrm{t}, 1 \mathrm{H}, J_{\mathrm{H}-\mathrm{H}} 7.6 \mathrm{~Hz}\right), 4.85(\mathrm{~s}, 5 \mathrm{H}), 2.63(\mathrm{~s}, 3 \mathrm{H})$ and $2.36(\mathrm{~s}, 3$ H). Satisfactory elemental analyses were obtained for 5 and $\mathbf{6}$.

$\dagger$ Crystal data for 5: $\mathrm{C}_{26} \mathrm{H}_{15} \mathrm{O}_{9} \mathrm{Os}_{3} \mathrm{~W}_{1}, M=1225.85$, triclinic, space group $P \overline{1}, a=8.158(3), b=11.080(2), c=15.519(3) \AA, \alpha=$ 106.29(1), $\beta=92.44(2), \gamma=109.96(3)^{\circ}, U=1251(1) \AA^{3}, Z=2, D_{c}=$ $3.255 \mathrm{~g} \mathrm{~cm}^{-3}, F(000)=1089, \lambda=0.70930 \AA, \mu(\mathrm{Mo}-\mathrm{K} \alpha)=19.95$ $\mathrm{mm}^{-1} . R=0.037, R_{\mathrm{w}}=0.033$ for total 4596 reflections and 3806 reflections with $I>2.0 \sigma(I)$. 6: $\mathrm{C}_{25} \mathrm{H}_{15} \mathrm{O}_{8} \mathrm{Os}_{3} \mathrm{~W}_{1}, M=1197.84$, triclinic, space group $P \overline{1}, a=9.465(2), b=15.963(5), c=$ $17.161(3) \AA, \alpha=97.45(2), \beta=103.07(2), \gamma=90.37(2)^{\circ}, U=2503(1)$ $\AA^{3}, Z=4, D_{c}=3.179 \mathrm{~g} \mathrm{~cm}^{-3}, F(000)=2123, \lambda=0.70930 \AA$ $\mu(\mathrm{Mo}-\mathrm{K} \alpha)=19.93 \mathrm{~mm}^{-1} . R=0.081, R_{\mathrm{w}}=0.076$ for total 6505 reflections and 5781 reflections with $I>2.0 \mathrm{\sigma}(I)$

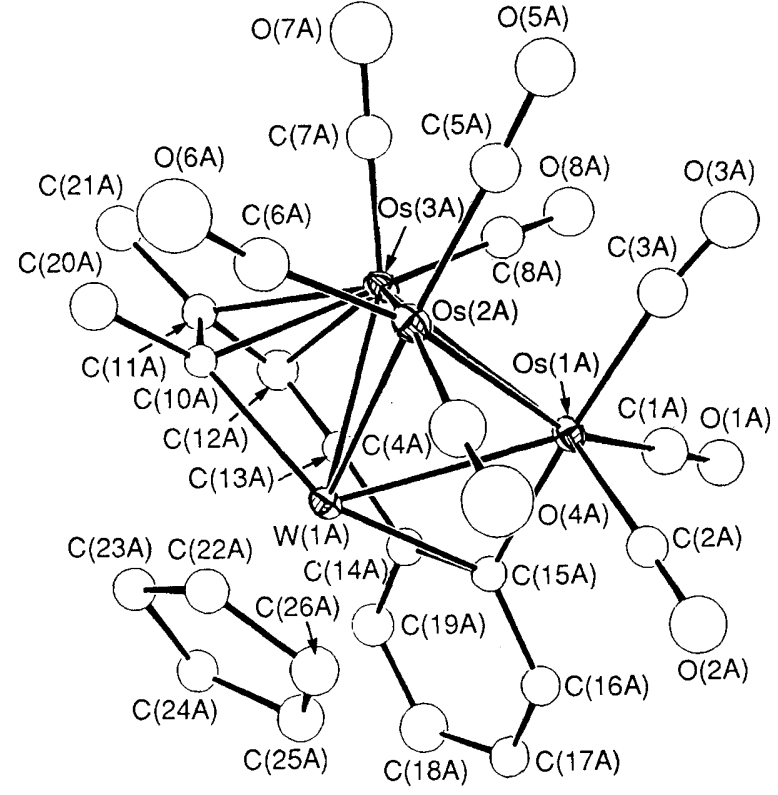

Fig. 3 The molecular drawing of 6 . Bond lengths $(\AA)$ : Os(1A)-Os(2A) 2.791(2), Os(1A)-Os(3A) 2.847(2), Os(1A)-W(1A) 2.826(2), $\mathrm{Os}(2 \mathrm{~A})-\mathrm{Os}(3 \mathrm{~A}) 2.827(2), \mathrm{Os}(2 \mathrm{~A})-\mathrm{W}(1 \mathrm{~A})$ 2.751(2), Os(3A)-W(1A) 2.735(2), Os(1A)-C(15A) 2.07(4), Os(3A)-C(10A) 2.28(3), Os(3A)$\mathrm{C}(11 \mathrm{~A}) 2.26(3), \mathrm{Os}(3 \mathrm{~A})-\mathrm{C}(12 \mathrm{~A}) 2.24(4), \mathrm{Os}(3 \mathrm{~A})-\mathrm{C}(13 \mathrm{~A}) 2.17(3)$, $\mathrm{W}(1 \mathrm{~A})-\mathrm{C}(10 \mathrm{~A})$ 2.17(3), W(1A)-C(13A) 2.13(4), W(1A)-C(14A) $2.45(4), C(10 \mathrm{~A})-\mathrm{C}(11 \mathrm{~A}) 1.39(5), \mathrm{C}(11 \mathrm{~A})-\mathrm{C}(12 \mathrm{~A}) 1.43(5), \mathrm{C}(12 \mathrm{~A})-$ $\mathrm{C}(13 \mathrm{~A}) 1.34(5), \mathrm{C}(13 \mathrm{~A})-\mathrm{C}(14 \mathrm{~A}) 1.43(4), \mathrm{C}(14 \mathrm{~A})-\mathrm{C}(15 \mathrm{~A})$ 1.49(4), $\mathrm{C}(14 \mathrm{~A})-\mathrm{C}(19 \mathrm{~A})$ 1.49(5), C(15A)-C(16A) 1.44(5), C(16A)-C(17A) $1.35(6), C(17 \mathrm{~A})-\mathrm{C}(18 \mathrm{~A}) 1.43(6)$ and $\mathrm{C}(18 \mathrm{~A})-\mathrm{C}(19 \mathrm{~A}) 1.38(6)$

able metal-metal and metal-substrate bonding interactions for chemisorbed hydrocarbons on catalytic surfaces.

We thank the National Science Council of the Republic of China for support of this research project (Grant No. NSC80-0208-M007-60)

\section{Received, 6th March 1991; Com. 1/01066B}

\section{References}

1 R. D. Adams, in The Chemistry of Metal Cluster Complexes, eds. D. F. Shriver, H. D. Kaesz and R. D. Adams, VCH, New York, 1990 , ch. 3

2 Y. Chi, D.-K. Hwang, S.-F. Chen and L.-K. Liu, J. Chem. Soc., Chem. Commun., 1989, 1540; D.-K. Hwang, Y. Chi, S.-M. Peng and G.-H. Lee, Organometallics, 1990, 9, 2709; Y. Chi, G.-H. Lee, S.-M. Peng and C.-H. Wu, Organometallics, 1989, 8, 1574 D.-K. Hwang, Y. Chi, S.-M. Peng, and G.-H. Lee, J. Organomet. Chem., 1990, 389, C7; Y. Chi. L.-K. Liu, G. Huttner and L. Zsolnai, J. Organomet. Chem., 1990, 390, C50.

3 Y. Chi, C.-Y. Cheng and S.-L. Wang, J. Organomet. Chem., 1989, 378, 45; Y. Chi, F.-J. Wu, B.-J. Liu, C.-C. Wang and S.-L. Wang, J. Chem. Soc., Chem. Commun., 1989, 873; Y. Chi, S.-H. Chuang, B.-F. Chen, S.-M. Peng and G.-H. Lee, J. Chem. Soc., Dalton Trans., 1990, 3033

4 M. I. Bruce, M. G. Humphrey, J. G. Matisons, S. K. Roy and A. G. Swincer, Aust. J. Chem., 1984, 37, 1955.

5 B. F. G. Johnson, R. Khattar, J. Lewis, P. R. Raithby and D. N. Smit, J. Chem. Soc., Dalton Trans., 1988, 1421.

6 Y. Chi, C.-H. Wu, S.-M. Peng and C.-H. Lee, Organometallics, $1990,9,2305$.

7 Y. Chi, H.-F. Hsu, S.-M. Peng and G.-H. Lee, J. Chem. Soc. Chem. Commun., the preceding paper.

8 A. J. Deeming, $A d v$. Organomet. Chem., 1986, 26, 1; G. Ferraris and G. Gervasio, J. Chem. Soc., Dalton Trans., 1972, 1057.

9 A. J. Deeming, S. E. Kabir, N. I. Powell, P. A. Bates and M. B. Hursthouse, J. Chem. Soc., Dalton Trans., 1987, 1529; M. I. Bruce, P. A. Humphery, O. B. Shawkataly, M. R. Snow, E. R. T. Tiekink and W. R. Cullen, Organometallics, 1990, 9, 2910.

10 P. A. Jackson, B. F. G. Johnson, J. Lewis, A. D. Massey D. Braga, C. Gradella and F. Grepioni, J. Organomet. Chem., 1990, 391, 225. 